\title{
ANALISIS KESESUAIAN PERAIRAN UNTUK BUDIDAYA IKAN KERAPU MACAN (Epinephelus fuscoguttatu) DI PERAIRAN PULAU TEGAL KECAMATAN TELUK PANDAN KABUPATEN PESAWARAN
}

\author{
Glenn Valentino*1, Abdullah Aman Damai, dan Herman Yulianto*2 \\ DOI: http://dx.doi.org/10.23960/jrtbp.v6i2.p705-712
}

\begin{abstract}
Tiger grouper is a marine aquaculture commodities that has good prospects to be developed. One of the areas that could potentially be used as a place of tiger grouper fish farming is the Tegal Island, Pesawaran. The purpose of this research was to analyze the level of water quality for fish farming tiger grouper (Epinephelus fuscoguttatus). This research was carried out in March-May 2017 descriptive analytic nature by doing the observations on the quality of waters which include physical and chemical parameters. The data that used in this research sourced from primary data about the suitability waters of the island while the secondary data is form in research location maps. There were 4 sampling stations which determined with global positioning system (GPS). The results showed that the water quality which is owned by the island's waters on station 1, 2, 3 and 4 were in the quite appropriate category for the cultivation of tiger grouper.
\end{abstract}

Keywords : Tegal Island, tiger grouper, water analyses

\section{Pendahuluan}

Ikan kerapu macan merupakan komoditas budidaya laut yang memiliki prospek yang baik untuk dikembangkan.Salah satu daerah yang berpotensi dijadikan tempat budidaya ikan kerapu di teluk lampung adalah Perairan Pulau Tegal Kabupaten Pesawaran. Beberapa keramba jaring apung (KJA) sudah ada di pulau tegal, akan tetapi pemanfaatan budidaya belum maksimal, sehingga hasil produksi yang ada tidak optimal. Tujuan dari penelitian menganalisis kualitas air untuk budidaya ikan kerapu macan
(Epinephelus

fuscoguttatus) berdasarkan parameter fisika dan kimia sehingga dengan data tersebut dapat menentukan kesesuaian perairan untuk budidaya kerapu macan.

\section{Metode}

Penelitian ini dilaksanakan pada bulan Maret - Mei 2017 di Perairan Pulau Tegal, Kecamatan Teluk Pandan, Kabupaten Pesawaran, Provinsi Lampung. Alat yang digunakan pada penelitian yaitu termometer, $\mathrm{pH}$ meter, secchi disk, pemberat manual, hand

\footnotetext{
${ }^{1}$ E-mail: glennvalentino3@gmail.com

${ }^{2}$ Jurusan Perikanan dan kelautan, Fakultas Pertanian, Universitas Lampung

Jl. Prof. S. Brodjonegoro No.1 Gedong Meneng Bandar Lampung 35145
} 
refractometer, DO meter, spektrofotometer, pengukur arus manual, stopwatch, dan GPS. Pengukuran parameter kualitas air dilakukan pada pukul 07.00 wib, 12.00 wib, 17.00 wib. Data primer meliputi data kesesuaian perairan

Pulau Tegal sedangkan data sekunder berupa peta lokasi kegiatan.

Stasiun rencana pengambilan sampel sebanyak 4 stasiun penentuan titik stasiun yang ditentukan dengan bantuan Global Positioning System (GPS) dapat dilihat pada Tabel 1 dan Gambar 1.

Tabel 1. Koordinat stasiun penelitian

\begin{tabular}{|c|c|c|c|}
\hline \multirow[b]{2}{*}{ No } & \multicolumn{2}{|c|}{ Koordinat } & \multirow[b]{2}{*}{ Ket } \\
\hline & $\begin{array}{l}\text { Lintang } \\
\text { Selatan }\end{array}$ & Bujur Timur & \\
\hline 1 & $5^{\circ} 33^{\prime} 36,49^{\prime \prime}$ & $105^{\circ} 16^{\prime} 22,04^{\prime \prime}$ & Dekat dengan KJA \\
\hline 2 & $5^{\circ} 33^{\prime} 40,75^{\prime \prime}$ & $105^{\circ} 16^{\prime} 31,16^{\prime \prime}$ & Daerah dekat dengan terumbu karang \\
\hline 3 & $5^{\circ} 33^{\prime} 30,33^{\prime \prime}$ & $105^{\circ} 16^{\prime} 33,44^{\prime \prime}$ & Dekat dengan permukiman \\
\hline 4 & $5^{\circ} 33^{\prime} 24,95^{\prime \prime}$ & $105^{\circ} 16^{\prime} 20,53^{\prime \prime}$ & $\begin{array}{c}\text { Di antara Pantai Sari Ringgung dan } \\
\text { Pulau Tegal }\end{array}$ \\
\hline
\end{tabular}

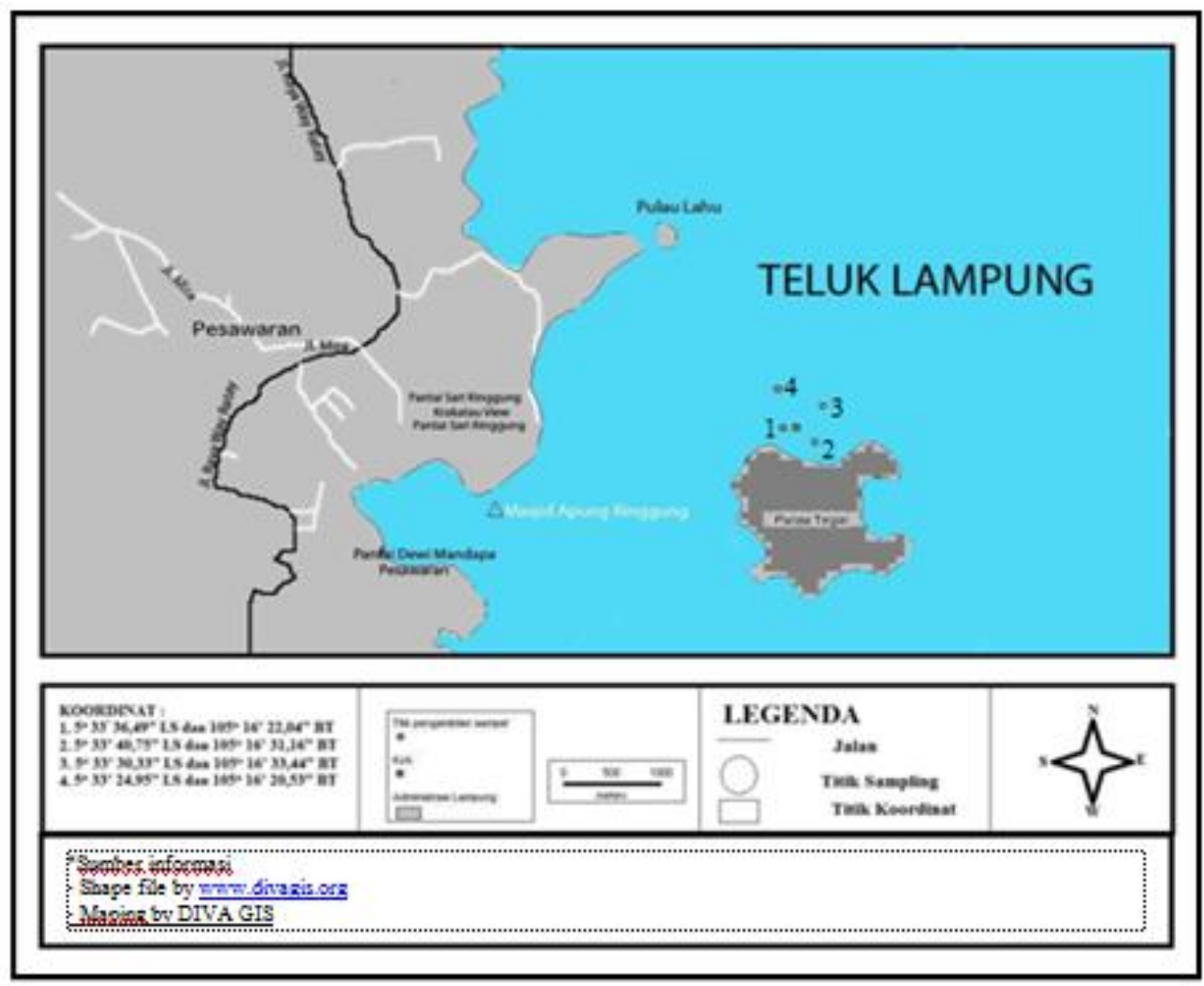

Gambar 1. Peta lokasi stasiun penelitian 
Parameter yang diamati antara lain Parameter fisika meliputi kedalaman perairan, kecerahan perairan, suhu dan kecepatan arus. Serta parameter kimia meliputi kandungan oksigen terlarut (DO), $\mathrm{pH}$, salinitas, Nitrat (NO3-N), dan Fosfat (PO4).

Penilaian parameter kualitas air untuk analisa kesesuaian perairan dapat dilihat pada Tabel 2.

Tabel 2. Penilaian parameter kualitas air untuk analisa kesesuaian lahan

\begin{tabular}{|c|c|c|c|c|c|}
\hline Parameter & Kelas & $\begin{array}{l}\text { Angka } \\
\text { Penilaian } \\
\text { (A) }\end{array}$ & $\begin{array}{c}\text { Bobot } \\
\text { (B) }\end{array}$ & (A) $X(B)$ & Sumber \\
\hline Oksigen & $\geq 5,0$ & 5 & & & Evalawati \\
\hline Terlarut & $\geq 4,0-4,9$ & 3 & 3 & 15 & et al. \\
\hline$(\mathrm{mg} / \mathrm{l})$ & $\leq 3,9$ & 1 & & & (2001) \\
\hline Kedalaman & $15,0-24,9$ & 5 & & & \\
\hline $\begin{array}{l}\text { Perairan } \\
\text { (meter) }\end{array}$ & $\begin{array}{c}5,0-14,9 \text { dan } 25-34,9 \\
\leq 4,9 \text { dan } \geq 35\end{array}$ & $\begin{array}{l}3 \\
1\end{array}$ & 3 & 15 & (2001) \\
\hline Kecepatan & $20,0-49,9$ & 5 & & & \\
\hline $\begin{array}{l}\text { Arus } \\
(\mathrm{cm} / \text { detik })\end{array}$ & $\begin{array}{c}0,0-19,9 \text { dan } 50-69,9 \\
\geq 75\end{array}$ & $\begin{array}{l}3 \\
1\end{array}$ & 3 & 15 & $\begin{array}{l}\text { BВPBL } \\
(2001)\end{array}$ \\
\hline Kecerahan & $\geq 5,0$ & 5 & & & \\
\hline $\begin{array}{l}\text { Perairan } \\
\text { (meter) }\end{array}$ & $\begin{array}{c}\geq 3-4,9 \\
\leq 2,9\end{array}$ & $\begin{array}{l}3 \\
1\end{array}$ & 3 & 15 & $\begin{array}{l}\text { Hargreave } \\
\text { s (1999) }\end{array}$ \\
\hline $\begin{array}{l}\text { Suhu } \\
\text { Perairan }\left(^{\circ}\right. \\
\text { C) }\end{array}$ & $\begin{aligned} & 27,0-30,9 \\
25,0- & 28,9 \text { dan } 31-31,9 \\
< & 24,9 \text { dan } \geq 32\end{aligned}$ & $\begin{array}{l}5 \\
3 \\
1\end{array}$ & 2 & 10 & $\begin{array}{c}\text { Romimoh } \\
\text { tarto dan } \\
\text { Juwana } \\
(1999)\end{array}$ \\
\hline Salinitas & $30,0-32,9$ & 5 & & & Evalawati \\
\hline $\begin{array}{l}\text { Perairan } \\
\quad(p p t)\end{array}$ & $\begin{array}{c}20,0-29,0 \\
\leq 19,9 \text { dan } \geq 33\end{array}$ & $\begin{array}{l}3 \\
1\end{array}$ & 2 & 10 & $\begin{array}{l}\text { et al. } \\
(2001)\end{array}$ \\
\hline $\mathrm{Ph}$ & $\begin{array}{c}8,0-8,20 \\
4,0-7,9 \text { dan } 8,20-8,9 \\
\leq 3,90 \text { dan } \geq 9.0\end{array}$ & $\begin{array}{l}5 \\
3 \\
1\end{array}$ & 2 & 10 & $\begin{array}{l}\text { Ghufron } \\
(2010)\end{array}$ \\
\hline $\begin{array}{l}\text { Fosfat } \\
(\mathrm{mg} / \mathrm{l})\end{array}$ & $\begin{array}{l}\geq 0,2-\leq 0,5 \\
\geq 0,5-0,7 \\
<0,2 \text { dan }>0,8\end{array}$ & $\begin{array}{l}5 \\
3 \\
1\end{array}$ & 1 & 5 & $\begin{array}{c}\text { Wardoyo } \\
(2002)\end{array}$ \\
\hline $\begin{array}{l}\text { Nitrat } \\
(\mathrm{mg} / \mathrm{l})\end{array}$ & $\begin{array}{c}0,90-3,19 \\
0,69-0,89 \text { dan } 3,2-3,39 \\
\leq 0,7 \text { dan } \geq 3,4\end{array}$ & $\begin{array}{l}5 \\
3 \\
1\end{array}$ & 1 & 5 & $\begin{array}{l}\text { Winanto } \\
(2004)\end{array}$ \\
\hline $\begin{array}{c}\text { Total } \\
\text { Skoring }\end{array}$ & & & & 100 & \\
\hline
\end{tabular}

Total skor merupakan hasil perkalian antara angka penilaian parameter (A) dengan bobotnya (B) untuk menentukan klas kesesuaian lahan budidaya ikan kerapu macan berdasarkan karakteristik kualitas perairan.

Berdasarkan nilai analisis kesesuaian perairan digolongkan dalam beberapa kelas dan dapat dilihat pada Tabel 3 .
Tabel 3. Nilai analisis kesesuaian perairan

\begin{tabular}{cccc}
\hline Kelas & & Keterangan & Nilai \\
\hline S1 & $:$ & Sangat Sesuai & $86-$ \\
& & & $100 \%$ \\
S2 & $:$ & Cukup Sesuai & $76-85 \%$ \\
S3 & $:$ & Sesuai & $66-75 \%$ \\
& & Marginal & \\
N & $:$ & Tidak Sesuai & $0-65 \%$
\end{tabular}

(Sumber: Cornelia, 2005) 


\section{Hasil dan Pembahasan}

\section{Parameter Kualitas Air}

Hasil pengukuran parameter fisika kimia perairan di Pulau Tegal dapat dilihat pada Tabel 4.

Tabel 4. Hasil pengukuran kualitas air di Perairan Pulau Tegal

\begin{tabular}{lccc}
\hline Variabel & Kisaran & $\begin{array}{c}\text { Rata- } \\
\text { rata }\end{array}$ & Keterangan \\
\hline $\begin{array}{l}\text { Kedalaman } \\
\text { (meter) }\end{array}$ & $13-27$ & 22,15 & In situ \\
$\begin{array}{l}\text { Oksigen } \\
\text { Terlarut } \\
\text { (mg/l) }\end{array}$ & $7,30-9,54$ & 7,94 & In situ \\
$\begin{array}{l}\text { Kecerahan } \\
\text { (meter) }\end{array}$ & $5-12,5$ & 8,33 & In situ \\
$\begin{array}{l}\text { Salinitas } \\
\text { (ppt) }\end{array}$ & 32 & 32 & In situ \\
$\begin{array}{l}\text { Suhu }{ }^{\circ} \mathrm{C} \\
\text { Kecepatan }\end{array}$ & $29,3-30,2$ & 29,74 & In situ \\
$\begin{array}{l}\text { arus } \\
\text { (cm/detik) }\end{array}$ & $0,05-0,12$ & 0,08 & In situ \\
$\begin{array}{l}\text { Ph } \\
\text { Nitrat } \\
\text { (mg/l) }\end{array}$ & $0,828-0,999$ & 0,902 & Lab. \\
$\begin{array}{l}\text { Fosfat } \\
\text { (mg/l) }\end{array}$ & $0,374-0,576$ & 0,415 & $\begin{array}{c}\text { Lab. } \\
\text { B }\end{array}$ \\
\hline
\end{tabular}

Hasil pengukuran nilai kedalaman perairan di Pulau Tegal dapat dilihat pada Gambar 2.

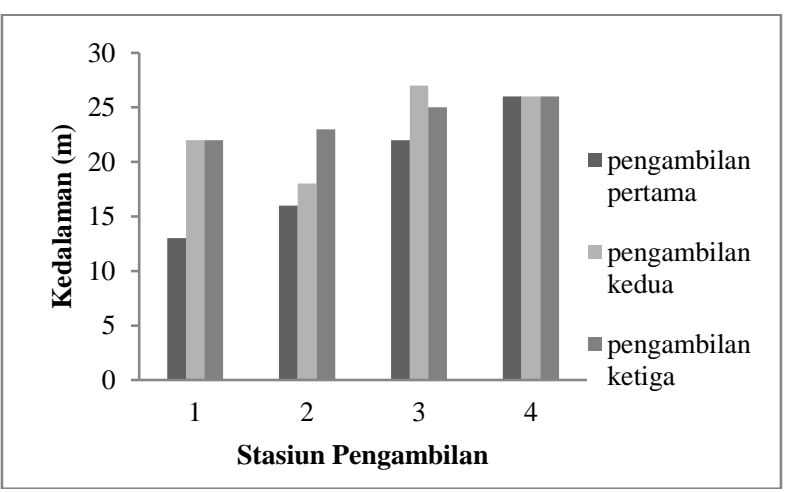

Gambar 2. Kedalaman di Perairan Pulau Tegal

Hasil pengukuran kedalaman perairan pada Gambar 1 di perairan pulau tegal berkisar $13 \mathrm{~m}-27 \mathrm{~m}$, dengan kedalaman rata-rata $22,16 \mathrm{~m}$. Hal ini karena relief permukaan laut yang tidak merata, sehingga terdapat perbedaan yang signifikan antara stasiun 1 dan stasiun 2. Menurut Radiarta (2007) nilai kedalaman yang optimal untuk budidaya ikan kerapu macan yaitu $6-28 \mathrm{~m}$, maka nilai kedalaman di perairan ini mencapai kelas yang sesuai untuk budidaya.

Hasil pengukuran nilai kandungan oksigen terlarut di perairan Pulau Tegal dapat dilihat pada Gambar 3.

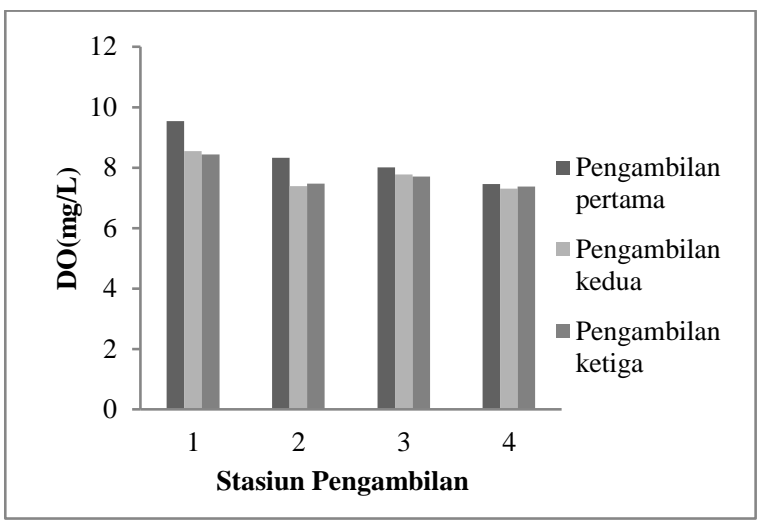

Gambar 3. Kandungan oksigen terlarut (DO) di Perairan Pulau Tegal selama penelitian

Kandungan oksigen terlarut di perairan Pulau Tegal berada pada kisaran 7,30 mg/l sampai dengan 9, $54 \mathrm{mg} / \mathrm{l}$ dengan nilai rata-rata 7,94 $\mathrm{mg} / \mathrm{l}$. Menurut (Evalawati $d k k, 2001$ ), ikan kerapu macan dapat hidup layak 
dalam karamba jaring apung dengan konsentrasi oksigen terlarut $>5 \mathrm{mg} / \mathrm{l}$.

Hasil pengukuran nilai kecerahan perairan di Pulau Tegal dapat dilihat pada Gambar 4.

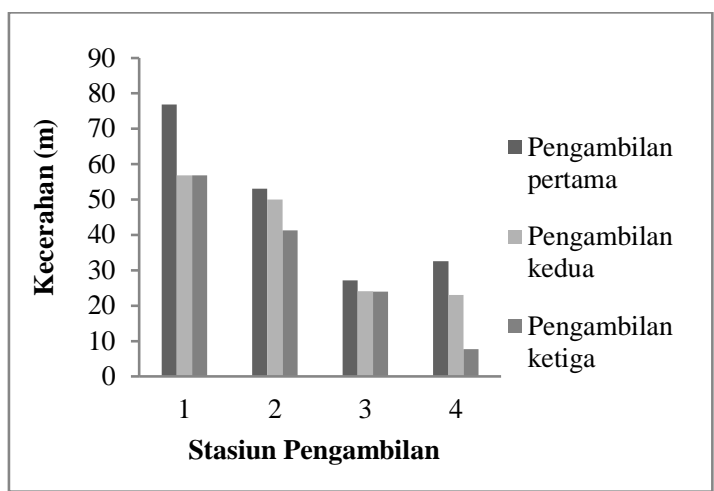

Gambar 4. Nilai kecerahan Perairan Pulau Tegal selama penelitian

Kecerahan perairan Pulau Tegal di stasiun penelitian berkisar antara 5 $-12,5 \mathrm{~m}$, dengan rata-rata $8,32 \mathrm{~m}$. Hal ini sesuai dengan pendapat Hargreaves and John (2002) kecerahan yang baik untuk pembesaran ikan kerapu macan adalah $\geq 5,00$ meter. Kecerahan air bisa digunakan sebagai indikator daya tembus penetrasi cahaya ke dalam air laut. Karena semakin keruh suatu perairan maka sumber cahaya semakin sedikit, maka tingkat kecerahan juga rendah.

Nilai Salinitas yang diperoleh selama penelitian di perairan Pulau Tegal ialah 32 ppt, Terlihat bahwa salinitas perairan Pulau Tegal relatif stabil. Hal ini sesuai dengan pendapat Evalawati $d k k$ (2001) salinitas yang ideal untuk pembesaran ikan kerapu macan adalah $30-33$ ppt.

Hasil pengukuran nilai suhu di perairan Pulau Tegal dapat dilihat pada Gambar 5.

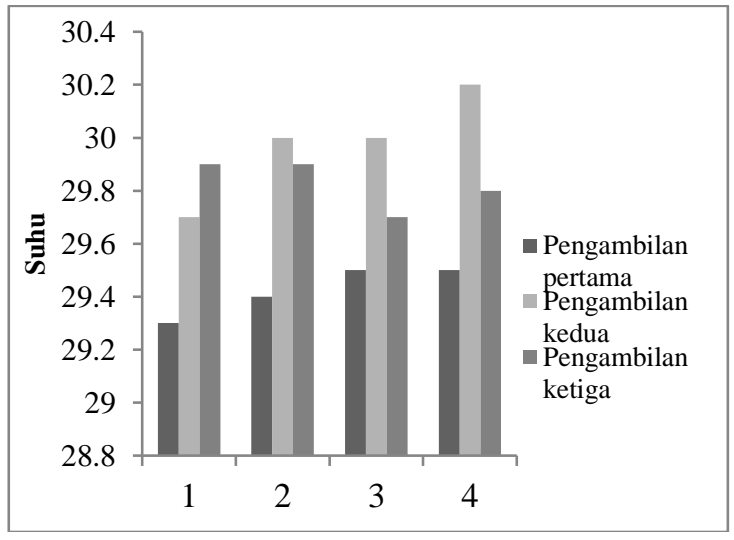

Gambar 5. Suhu di Perairan Pulau Tegal selama Penelitian

Suhu perairan pulau Tegal didapatkan hasil yaitu $29,3-30,2^{\circ} \mathrm{C}$ dengan rata-rata $29,73{ }^{\circ} \mathrm{C}$. Hasil tersebut sangat baik untuk mendukung budidaya ikan kerapu macan. hal ini sesuai dengan pendapat Effendi, (2003) bahwa suhu yang baik untuk budidaya kerapu macan ialah $30^{\circ} \mathrm{C}$. Selain itu sesuai dengan pendapat Nontji (2007) suhu yang baik untuk perkembangan budidaya ikan kerapu macan adalah $27,0{ }^{\circ} \mathrm{C}-$ $30,9^{\circ}$. Suhu air dipengaruhi oleh radiasi cahaya matahari, udara, cuaca dan lokasi.

Hasil pengukuran nilai kecepatan arus di perairan Pulau Tegal dapat dilihat pada Gambar 6.

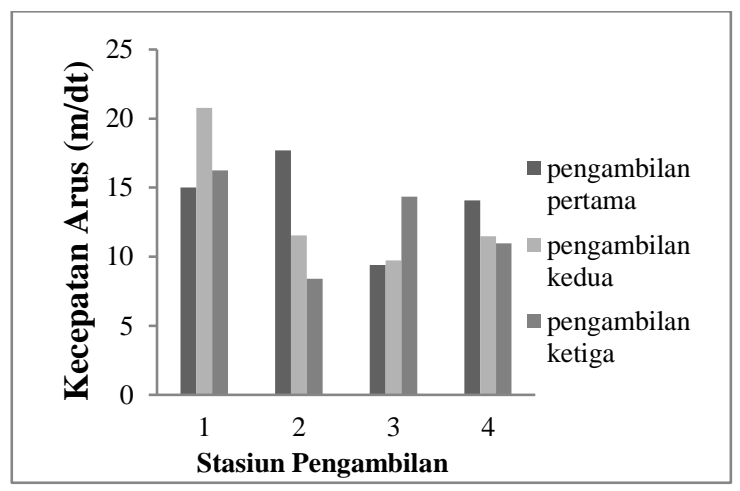

Gambar 6. Kecepatan arus di Perairan Pulau Tegal selama penelitian 
Kecepatan arus perairan Pulau Tegal selama penelitian berkisar antara $0,04 \mathrm{~m} / \mathrm{dt}$ sampai dengan 0,11 $\mathrm{m} / \mathrm{dt}$ dengan rata-rata $0,075 \mathrm{~m} / \mathrm{dt}$. Hal ini sesuai dengan pendapat Kecepatan arus yang ideal untuk pembesaran ikan kerapu macan adalah antara 0,2 - $0,5 \mathrm{~m} / \mathrm{dt}$ (BBPBL, 2001). Sedangkan Evalawati $d k k$ (2001) menganjurkan kisaran yang baik untuk budidaya kerapu macan adalah $0,15-0,3 \mathrm{~m} / \mathrm{dt}$.

Hasil pengukuran nilai $\mathrm{pH}$ di perairan Pulau Tegal dapat dilihat pada Gambar 7.

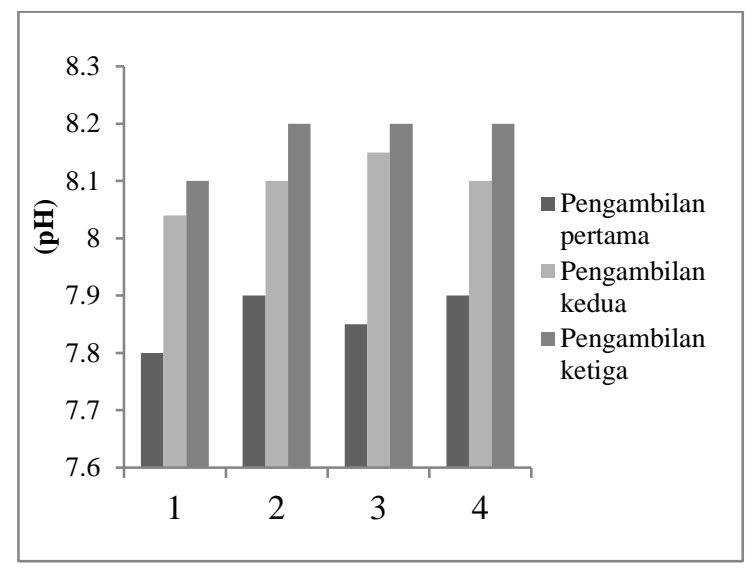

Gambar 7. pH di Perairan Pulau Tegal selama penelitian

Nilai $\mathrm{pH}$ dari perairan pulau Tegal yaitu 7,8 - 8,15 dengan ratarata nilai $\mathrm{pH} 8,07$. Nilai $\mathrm{pH}$ yang diperoleh dalam kondisi baik. Hal ini sesuai dengan pendapat Ghufran (2010) ikan kerapu macan diketahui sangat baik pertumbuhannya pada $\mathrm{pH}$ normal air laut yaitu antara $6,0-8,2$. Apabila terjadi perubahan asam atau basa di perairan dapat mengganggu sistem keseimbangan ekologi, selain itu $\mathrm{pH}$ air mempengaruhi tingkat kesuburan perairan karena mempengaruhi kehidupan jasad renik langsung dari fotosintesis yang menggunakan $\mathrm{CO}_{2}$ selama proses tersebut.

Hasil pengukuran kandungan nitrat di perairan Pulau Tegal dapat dilihat pada Gambar 8.

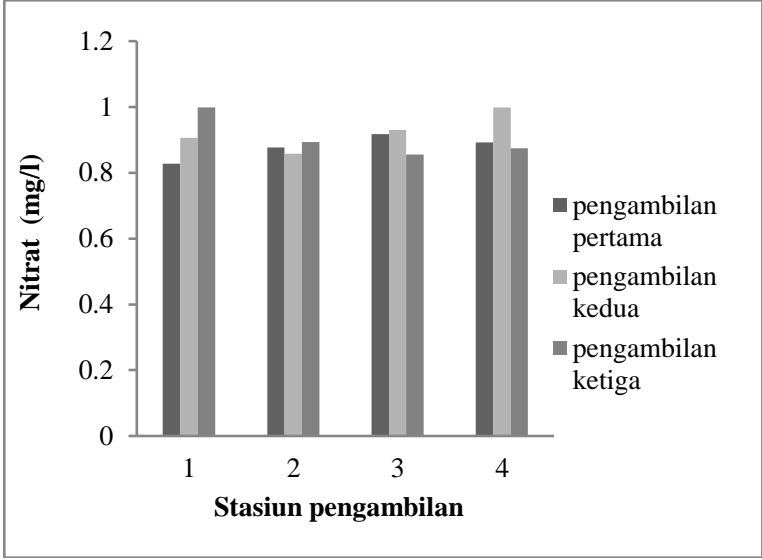

Gambar 8. Kandungan nitrat di Perairan Pulau Tegal selama penelitian

Kandungan nitrat perairan Pulau Tegal selama penelitian berkisar antara $0,828 \mathrm{mg} / \mathrm{L}$ sampai dengan $0,999 \mathrm{mg} / \mathrm{l}$. Hal ini sesuai dengan pendapat Winanto (2004) bahwa kisaran nitrat yang layak untuk organisme yang dibudidayakan sekitar 0,90 - 3,19 mg/l.

Hasil pengukuran nilai kandungan fosfat di perairan Pulau Tegal dapat dilihat pada Gambar 9. 


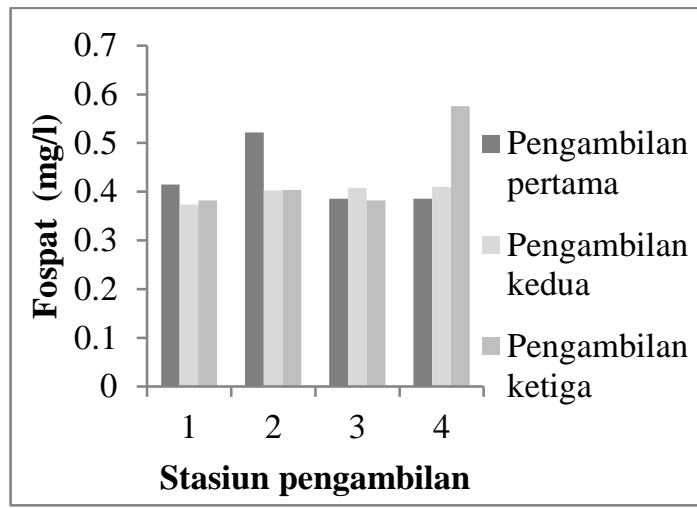

Gambar 9. Kandungan fosfat di Perairan Pulau Tegal selama penelitian

Kandungan fosfat perairan Pulau Tegal berada pada kisaran $0,374 \mathrm{mg} / \mathrm{l}$ sampai dengan $0,522 \mathrm{mg} / \mathrm{l}$, dengan rata-rata nilai $0,420 \quad \mathrm{mg} / \mathrm{l}$. Jika kandungan fosfat lebih dari 0,051 ppm maka perairan bisa dikatakan baik (Wardoyo, 2002).

\section{Kesesuaian Perairan Pulau Tegal}

Pengukuran kualitas air di perairan Pulau Tegal menunjukkan hasil yang baik. Setelah dilakukan pengolahan data, pembobotan dan skoring berdasarkan sistem penilaian kesesuaian perairan untuk budidaya ikan kerapu macan pada stasiun 1 dapat dilihat pada Tabel 5.

Tabel 5. Pembobotan dan skoring kesesuaian stasiun 1 Perairan Pulau Tegal untuk budidaya kerapu macan

\begin{tabular}{lcccc}
\hline Variabel & $\begin{array}{c}\text { Rata- } \\
\text { Rata }\end{array}$ & $\begin{array}{c}\text { Angka } \\
\text { Penilaian } \\
(\mathbf{A})\end{array}$ & $\begin{array}{c}\text { Bobot } \\
(\mathbf{B})\end{array}$ & $\begin{array}{c}\text { Skor } \\
(\mathbf{A x B})\end{array}$ \\
\hline $\begin{array}{l}\text { Oksigen } \\
\text { Terlarut } \\
\text { (mg/l) }\end{array}$ & 8,83 & 5 & 3 & 15 \\
$\begin{array}{l}\text { Kedalaman } \\
\text { (meter) }\end{array}$ & 19 & 5 & 3 & 15 \\
$\begin{array}{l}\text { Kecepatan } \\
\text { Arus } \\
\text { (cm/detik) }\end{array}$ & 0,05 & 3 & 3 & 9 \\
$\begin{array}{l}\text { Kecerahan } \\
\text { (meter) }\end{array}$ & 0,62 & 1 & 3 & 3
\end{tabular}

\section{Suhu}

Salinitas

Perairan

(ppt)

$\mathrm{pH}$

Fosfat

$(\mathrm{mg} / \mathrm{l})$

Nitrat

$(\mathrm{mg} / \mathrm{l})$

Total

Skoring

Nilai

Skoring

$\begin{array}{cccc}29,63 & 5 & 2 & 10 \\ 32 & 5 & 2 & 10 \\ 8,1 & 5 & 2 & 10 \\ 0,390 & 5 & 1 & 5 \\ 0,910 & 5 & 1 & 5 \\ & & & \mathbf{8 2}\end{array}$

Berdasarkan sistem penilaian kesesuaian perairan untuk budidaya ikan kerapu macan pada stasiun 2 dapat dilihat pada Tabel 6 .

Tabel 6. Pembobotan dan skoring kesesuaian stasiun 2 Perairan Pulau Tegal untuk budidaya kerapu macan

\begin{tabular}{|c|c|c|c|c|}
\hline Variabel & $\begin{array}{l}\text { Rata- } \\
\text { Rata }\end{array}$ & $\begin{array}{c}\text { Angka } \\
\text { Penilaian } \\
\text { (A) }\end{array}$ & $\begin{array}{l}\text { Bobot } \\
\text { (B) }\end{array}$ & $\begin{array}{r}\text { Skor } \\
(\mathbf{A x B})\end{array}$ \\
\hline \multicolumn{5}{|l|}{ Oksigen } \\
\hline $\begin{array}{l}\text { Terlarut } \\
(\mathrm{mg} / \mathrm{l})\end{array}$ & 7,73 & 5 & 3 & 15 \\
\hline $\begin{array}{l}\text { Kedalaman } \\
\text { (meter) }\end{array}$ & 19 & 5 & 3 & 15 \\
\hline Kecepatan & & & & \\
\hline $\begin{array}{l}\text { Arus } \\
\text { (cm/detik) }\end{array}$ & 0,08 & 3 & 3 & 9 \\
\hline $\begin{array}{l}\text { Kecerahan } \\
\text { (meter) }\end{array}$ & 0,48 & 1 & 3 & 3 \\
\hline Suhu & 29,76 & 5 & 2 & 10 \\
\hline $\begin{array}{l}\text { Salinitas } \\
\text { Perairan } \\
\text { (ppt) }\end{array}$ & 32 & 5 & 2 & 10 \\
\hline $\mathrm{pH}$ & 8,06 & 5 & 2 & 10 \\
\hline $\begin{array}{l}\text { Fosfat } \\
(\mathrm{mg} / \mathrm{l})\end{array}$ & 0,443 & 5 & 1 & 5 \\
\hline $\begin{array}{l}\text { Nitrat } \\
(\mathrm{mg} / \mathrm{l})\end{array}$ & 0,876 & 3 & 1 & 3 \\
\hline $\begin{array}{l}\text { Total } \\
\text { Skoring }\end{array}$ & & & & 80 \\
\hline $\begin{array}{l}\text { Nilai } \\
\text { Skoring }\end{array}$ & & & & $80 \%$ \\
\hline
\end{tabular}

\section{0}

10

10

5

5

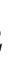

\section{nat}

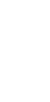



ikan kerapu macan pada stasiun 3
dapat dilihat pada Tabel 7.

Tabel 7. Pembobotan dan skoring kesesuaian stasiun 3 Perairan Pulau Tegal untuk budidaya kerapu macan

\begin{tabular}{|c|c|c|c|c|}
\hline Variabel & $\begin{array}{l}\text { Rata- } \\
\text { Rata }\end{array}$ & $\begin{array}{c}\text { Angka } \\
\text { Penilaian } \\
\text { (A) }\end{array}$ & $\begin{array}{c}\begin{array}{c}\text { Bobot } \\
\text { (B) }\end{array} \\
\end{array}$ & $\begin{array}{l}\text { Skor Fo } \\
(\mathrm{AxB})(\mathrm{m}\end{array}$ \\
\hline Oksigen & & & & \\
\hline $\begin{array}{l}\text { Terlarut } \\
(\mathrm{mg} / \mathrm{l})\end{array}$ & 7,37 & 5 & 3 & 15 \\
\hline $\begin{array}{l}\text { Kedalaman } \\
\text { (meter) }\end{array}$ & 24,7 & 5 & 3 & $15 \stackrel{S}{N}$ \\
\hline $\begin{array}{l}\text { Kecepatan } \\
\text { Arus }\end{array}$ & 0,08 & 3 & 3 & 9 \\
\hline $\begin{array}{l}(\mathrm{cm} / \text { detik) } \\
\text { Kecerahan } \\
\text { (meter) }\end{array}$ & 0,25 & 1 & 3 & 3 \\
\hline Suhu & 29,73 & 5 & 2 & 10 \\
\hline $\begin{array}{l}\text { Salinitas } \\
\text { Perairan } \\
\text { (ppt) }\end{array}$ & 32 & 5 & 2 & 10 \\
\hline $\mathrm{pH}$ & 8,06 & 5 & 2 & 10 \\
\hline $\begin{array}{l}\text { Fosfat } \\
(\mathrm{mg} / \mathrm{l})\end{array}$ & 0,392 & 5 & 1 & 5 \\
\hline $\begin{array}{l}\text { Nitrat } \\
(\mathrm{mg} / \mathrm{l})\end{array}$ & 0,901 & 5 & 1 & 5 \\
\hline $\begin{array}{l}\text { Total } \\
\text { Skoring }\end{array}$ & & & & 82 \\
\hline $\begin{array}{l}\text { Nilai } \\
\text { Skoring }\end{array}$ & & & & $82 \%$ \\
\hline
\end{tabular}

Berdasarkan sistem penilaian kesesuaian perairan untuk budidaya ikan kerapu macan pada stasiun 4 dapat dilihat pada Tabel 8 .

Tabel 8. Pembobotan dan skoring kesesuaian stasiun 3 Perairan Pulau Tegal untuk budidaya kerapu macan

\begin{tabular}{lcccc}
\hline Variabel & $\begin{array}{c}\text { Rata- } \\
\text { Rata }\end{array}$ & $\begin{array}{c}\text { Angka } \\
\text { Penilaian } \\
(\mathbf{A})\end{array}$ & $\begin{array}{c}\text { Bobot } \\
(\mathbf{B})\end{array}$ & $\begin{array}{c}\text { Skor } \\
(\mathbf{A x B})\end{array}$ \\
\hline $\begin{array}{l}\text { Oksigen } \\
\text { Terlarut } \\
\text { (mg/l) }\end{array}$ & 7,83 & 5 & 3 & 15 \\
$\begin{array}{l}\text { Kedalaman } \\
\text { (meter) }\end{array}$ & 26 & 3 & 3 & 9 \\
$\begin{array}{l}\text { Kecepatan } \\
\text { Arus } \\
\text { (cm/detik) }\end{array}$ & 0,08 & 3 & 3 & 9
\end{tabular}

Kecerahan (meter)

Suhu

Salinitas

Perairan

(ppt) $\mathrm{pH}$

(1)

$\begin{array}{cccc}0,24 & 1 & 3 & 3 \\ 29,84 & 5 & 2 & 10 \\ 32 & 5 & 2 & 10 \\ 8,06 & 5 & 2 & 10 \\ 0,457 & 5 & 1 & 5 \\ 0,922 & 5 & 1 & 5 \\ & & & \mathbf{7 6}\end{array}$

Skoring

$76 \%$

Pada hasil penelitian di stasiun 1 didapatkan hasil total skor 82 , stasiun 2 sebesar 80 , stasiun 3 sebesar 82 dan stasiun 4 sebesar 76 . Total skor yang didapat pada masing-masing stasiun masuk dalam kategori S2 yaitu cukup sesuai. Hal ini disebabkan pada hasil pengukuran parameter fisika meliputi kedalaman, kecepatan arus, kecerahan perairan, dan suhu masih dalam kondisi yang baik, sedangkan hasil pengukuran kimia meliputi oksigen terlarut, salinitas, ph, nitrat dan fosfat masih dalam kondisi yang baik. Selain itu faktor lingkungan di perairan Pulau Tegal masih terjaga dengan baik. Faktor lain yang mempengaruhi kondisi perairan pada stasiun-stasiun tersebut yaitu masih terdapat terumbu karang. Terumbu karang merupakan tempat organisme laut mencari makan, tempat pemijahan, tempat pengasuhan, tingginya produktivitas di perairan yang terdapat terumbu arang memungkinkan perairan tersebut masih dalam kondisi baik hal itu dibuktikan dengan adanya beberapa KJA disekitar perairan Pulau Tegal. 


\section{Kesimpulan dan Saran}

Hasil penelitian menyatakan bahwa perairan Pulau Tegal cukup sesuai untuk dilakukan budidaya ikan kerapu macan

\section{Daftar Pustaka}

Balai Besar Pengembangan Budidaya Laut (BBPBL) Lampung. 2001. Modul Petunjuk Teknis Pembesaran Kerapu. Balai Besar Pengembangan Budidaya Laut Lampung. Lampung: Departemen Kelautan dan Perikanan, Direktorat Jendral Perikanan Budidaya, Balai Budidaya Laut.

Cornelia, M. 2005. Modul Prosedur dan Spesifikasi Teknis Analisis Kesesuaian Budidaya Rumput Laut. Jakarta: Pusat Survey Sumberdaya Alam Laut.

Effendi, H. 2003. Telaah Kualitas Air Bagi Pengelolaan Sumberdaya dan Lingkungan Perairan. Yogyakarta: PT. Kanisius.

Evalawati, Meiyana, M., dan Aditya, T.W. 2001. Modul Pembesaran Kerapu Macan (Epinephelus fuscogutattus) Dan Kerapu Tikus (Epinephelus altivelis) di Keramba Jaring Apung. Lampung: Departemen Kelautan dan Perikanan, Direktorat Jendral Perikanan Budidaya, Balai Budidaya Laut

Ghufran, M.H. 2010. Pemeliharaan Ikan Kerapu Macan (Epinephelus fuscogutattus) di Keramba Jaring Apung. Jakarta: Akademia.

Hargreaves, J.A. 1999. Control of Clay Turbidity in Ponds. Southern Regional Aquaculture Center (SRAC), Publication No.460.
Nontji, A. 2007. Budidaya Kerapu Macan Dalam Keramba Jaring Apung. Cetakan kelima (Edisi Revisi). Jakarta: Penerbit Djambatan.

Radiarta, N., Wardoyo, S.E., Priono, B., dan Praseno, O. 2007. Aplikasi Sistem Informasi Geografis untuk Penentuan Lokasi Pengembangan Budidaya Laut di Teluk Ekas, Nusa Tenggara Barat. Jurnal Penelitian Perikanan Indonesia 9: 67-79.

Romimohtarto, K. dan Juwana, S. 1999. Biologi Laut: Ilmu Pengetahuan tentang Biota Laut. Jakarta: Pusat Penelitian dan Pengembangan Oseanologi. LIPI.

Wahyuni, K.A., Tjahjo, W., dan Anindiastuti. 2002. Budidaya Fitoplankton Skala Massal. Budidaya Fitoplankton dan Zooplankton . Seri Budidaya Laut No. 9. 57 - 59. Lampung: Departemen Kelautan dan Perikanan, Direktorat Jendral Perikanan Budidaya, Balai Budidaya Laut.

Wardoyo, S.T.H., 2002 . Water Analysis Manual Tropical Aquatic Biology Program. Bogor: Biotrop, Winanto. 2004. Memproduksi Benih Tiram Mutiara. Jakarta: Penebar Swadaya. 
